\title{
Osmium and cobalt complexes incorporating facially coordinated N,N,O donor azo-imine ligands: Redox and catalytic properties
}

\author{
POULAMI PATTANAYAK ${ }^{\mathrm{a}}$, DEBPRASAD PATRA $^{\mathrm{a}}$, JAHAR LAL PRATIHAR $^{\mathrm{a}}$, \\ ANDREW BURROWS $^{\mathrm{b}}$, MARY F MAHON ${ }^{\mathrm{b}}$ and SURAJIT CHATTOPADHYAY ${ }^{\mathrm{a}, *}$ \\ ${ }^{a}$ Department of Chemistry, University of Kalyani, Kalyani 741235, India \\ bepartment of Inorganic Chemistry, University of Bath, Claverton Down, Bath, BA27AY, UK \\ e-mail: scha8@rediffmail.com
}

MS received 25 July 2011; revised 29 August 2011; accepted 7 October 2012

\begin{abstract}
Reactions of 1-\{[2-(arylazo)phenyl]iminomethyl $\}$-2-phenol, HL [where $\mathrm{H}$ represents the dissociable phenolic protons of ligands and aryl groups of $\mathrm{HL}$ are $\left.\mathrm{C}_{6} \mathrm{H}_{5}\left(\mathrm{HL}^{1}\right), p-\mathrm{CH}_{3} \mathrm{C}_{6} \mathrm{H}_{5}\left(\mathrm{HL}^{2}\right), p-\mathrm{ClC}_{6} \mathrm{H}_{5}\left(\mathrm{HL}^{3}\right)\right]$ with $\mathrm{Os}(\mathrm{H})(\mathrm{CO})(\mathrm{Br})\left(\mathrm{PPh}_{3}\right)_{3}$ in toluene and with $\mathrm{Co}\left(\mathrm{ClO}_{4}\right)_{3} \cdot 6 \mathrm{H}_{2} \mathrm{O}$ in methanol afforded new facially coordinated complexes of composition $\left[(\mathrm{L}) \mathrm{Os}(\mathrm{CO})(\mathrm{Br})\left(\mathrm{PPh}_{3}\right)\right]$ and $\left[(\mathrm{L})_{2} \mathrm{Co}\right] \mathrm{ClO}_{4}$. The anionic ligand $(\mathrm{L})^{-}$, binds the metal in tridentate $(\mathrm{N}, \mathrm{N}, \mathrm{O})$ manner in $\left[(\mathrm{L}) \mathrm{Os}(\mathrm{CO})(\mathrm{Br})\left(\mathrm{PPh}_{3}\right)\right]$ and $\left[(\mathrm{L})_{2} \mathrm{Co}\right] \mathrm{ClO}_{4}$ complexes. All the Os(II) and $\mathrm{Co}$ (III) complexes are diamagnetic and show characteristic ${ }^{1} \mathrm{H}$ NMR signals and intense MLCT transitions in the visible region. The cyclic voltammograms exhibited one quasi reversible oxidative response near $0.10 \mathrm{~V}$ vs $\mathrm{SCE}$ for $\left[(\mathrm{L}) \mathrm{Os}(\mathrm{CO})(\mathrm{Br})\left(\mathrm{PPh}_{3}\right)\right]$ and $\left[(\mathrm{L})_{2} \mathrm{Co}\right] \mathrm{ClO}_{4}$ complexes displayed serial reductive responses within -0.06 to $-1.61 \mathrm{~V}$ vs SCE. Single point DFT calculation was carried out to examine the nature of redox orbitals. Conversion of ketones to corresponding alcohols has been studied using $\left[(\mathrm{L}) \mathrm{Os}(\mathrm{CO})(\mathrm{Br})\left(\mathrm{PPh}_{3}\right)\right]$ as catalyst.
\end{abstract}

Keywords. 2-(Arylazo)-1-N-salicylidene phenylamine; face capped Os(II); Co(III); DFT; redox; hydrogen transfer reaction.

\section{Introduction}

The ligands which bind the transition metal ion in a predictable way play important role in modern coordination chemistry since they may determine the reactive sites available at a metal centre and can modulate their reactivity.

Fascinating chemistry of transition metal complexes incorporating ligands that are capable of binding the metal centre in facial manner, enhanced the interest on the synthesis of new tridentate ligands that are suitable for obtaining facially coordinated complexes. ${ }^{1-7}$

Facially capped piano-stool type of platinum metal complexes have received attention due to their interesting catalytic and biological activity. Conversion of dimethyl oxalate to ethylene glycol and hydrogenation of esters to yield alcohols in homogeneous media using such metal complexes as catalyst are notable examples. ${ }^{8-21}$

Although several tridentate facially coordinating ligands, such as 1,4,7 tri aza cyclononane, 1,4,7 trithia cyclononane, tris pyrazolyl borate, a few scorpionate and tripodal ligands, are known to form facially capped

*For correspondence platinum metal complexes, ${ }^{22-34}$ but only a few of the above mentioned ligands have been utilized for the preparation of Os(II) complexes. ${ }^{35,36}$ As a consequence, chemistry of Os(II) complexes with facially coordinating ligands have not been explored considerably. Coordination chemistry of osmium incorporating azo ligands has been studied with a few bidentate $(\mathrm{N}, \mathrm{N}$ and $\mathrm{N}, \mathrm{O}$ donors) and tridentate $(\mathrm{C}, \mathrm{N}, \mathrm{O}$ and $\mathrm{N}, \mathrm{N}, \mathrm{N}$ donors) ligands. ${ }^{37-41}$ Whereas the coordination chemistry of osmium with tridentate $\mathrm{N}, \mathrm{N}, \mathrm{O}$ donor ligands has not been reported so far. These background information prompted us to study the coordination chemistry of osmium incorporating the $\mathrm{N}, \mathrm{N}, \mathrm{O}$ donor azo-imine ligand system, 1.

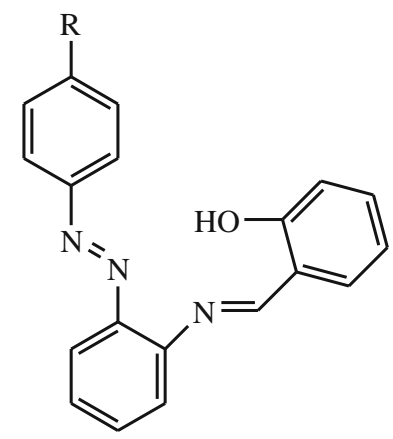

1 
In this paper, we have described the reactions of appropriate osmium and cobalt substrates with 1 to obtain Os(II) and $\mathrm{Co}$ (III) complexes where the tridentate $(\mathrm{N}, \mathrm{N}, \mathrm{O})$ ligand is facially coordinated. Spectroscopic and redox properties of new complexes have been described. Catalytic transfer of hydrogen reactions using newly synthesized Os(II) complexes as catalyst have been reported. A plausible description of redox orbitals have been ascribed on the basis of single point DFT calculations.

\section{Experimental}

\subsection{Materials}

The solvents used in the reactions were of reagent grade (obtained this from E Marck, Kolkata, India) and were purified and dried by reported procedure. ${ }^{42} \mathrm{Os}(\mathrm{H})(\mathrm{CO})(\mathrm{Br})\left(\mathrm{PPh}_{3}\right)_{3}$ was prepared according a reported procedure. ${ }^{43}$ Cobalt (III) perchlorate was prepared by oxidation of Co (II) perchlorate with $\mathrm{H}_{2} \mathrm{O}_{2} \cdot{ }^{44}$ 1-\{[2-(Arylazo)phenyl]iminomethyl $\}-2-$ phenol, HL [where $\mathrm{H}$ represents the dissociable protons upon complexation and aryl groups of HL are phenyl for $\mathrm{HL}^{1}$; $p$-methyl phenyl for $\mathrm{HL}^{2}$; $p$-chloro phenyl for $\mathrm{HL}^{3}$ ], were prepared according to a reported procedure. ${ }^{45}$

\subsection{Syntheses of complexes}

2.2a $\left[(\mathrm{L}) \mathrm{Os}(\mathrm{CO})(\mathrm{Br})\left(\mathrm{PPh}_{3}\right)\right]$ : The $\left[(\mathrm{L}) \mathrm{Os}(\mathrm{CO})(\mathrm{Br})\left(\mathrm{PPh}_{3}\right)\right]$ complexes were obtained by following a general procedure. Specific details are given below for a particular complex.

2.2b $\left[\left(L^{1}\right) O s(C O)(B r)\left(P P h_{3}\right)\right](\mathbf{2 a}):$ 2-(Phelazo)-1-Nsalicylidene phenylamine, $\mathrm{HL}^{1},(0.03 \mathrm{~g}, 0.102 \mathrm{mmol})$ was dissolved in $40 \mathrm{ml}$ toluene, and to it $\mathrm{Os}(\mathrm{H})(\mathrm{CO})(\mathrm{Br})\left(\mathrm{PPh}_{3}\right)_{3} \quad(0.10 \mathrm{~g}, 0.102 \mathrm{mmol})$ was added. The mixture was then heated to reflux for $8 \mathrm{~h}$ till the solution turned to dark brown. Evaporation of the solvent gave a dark brown residue, which was purified by thin-layer chromatography on silica gel. A green band separated in toluene-acetonitrile $(95: 5, \mathrm{~V} / \mathrm{V})$ mixed solvent. From the second band $\left[\left(\mathrm{L}^{1}\right) \mathrm{Os}(\mathrm{CO})(\mathrm{Br})\left(\mathrm{PPh}_{3}\right)\right]$ was isolated in pure form upon extracting with dichloromethane and methanol. Yield: 70\%. Anal. calc. for 2a. C 52.97, H 3.36, N 4.87. Found: C 53.00, H 3.34, N 4.90\%. Electronic spectrum $\left(\lambda_{\max } / \mathrm{nm}\left(\varepsilon / \mathrm{dm}^{2} \mathrm{~mol}^{-1}\right)\right.$, dichloromethane):
650 (4570), 470 (4570), 350 (19380), 255 (29850), 240 (40790). IR ( $\mathrm{KBr}$ pellets, $\mathrm{cm}^{-1}$ ): $v_{\mathrm{C}=\mathrm{N}} 1605, v_{\mathrm{N}=\mathrm{N}}$ $1434, v_{\mathrm{CO}} 1920 .{ }^{1} \mathrm{H} \mathrm{NMR}\left(\mathrm{CDCl}_{3} \mathrm{ppm}\right): \delta 8.27(\mathrm{~d}, 2 \mathrm{H})$, 7.94-7.92 (d, 1H), $7.62(\mathrm{t}, 6 \mathrm{H}), 7.53-7.42(\mathrm{~m}, 6 \mathrm{H})$, $7.42-7.39$ (m, 3H), 7.32-7.25 (m, 9H), 7.17-7.15 $(\mathrm{t}, 1 \mathrm{H}), 7.04(\mathrm{~s}, 1 \mathrm{H}), 6.83(\mathrm{~d}, 1 \mathrm{H}), 6.62(\mathrm{~d}, 1 \mathrm{H}), 6.46(\mathrm{~d}$, $1 \mathrm{H}), 6.28(\mathrm{t}, 1 \mathrm{H}) \mathrm{ppm} . E_{1 / 2}[\mathrm{~V}]\left(\Delta \mathrm{E}_{p} / \mathrm{mV}\right): 1.1$.

2.2c and 2.2.d $\left[\left(L^{2}\right) O s(C O)(B r)\left(P P h_{3}\right)\right](2 \mathbf{b})$ and $\left[\left(\mathrm{L}^{3}\right) \mathrm{Os}(\mathrm{CO})(\mathrm{Br})\left(\mathrm{PPh}_{3}\right)\right]$ (2c): The complexes $\left[\left(\mathrm{L}^{2}\right) \mathrm{Os}(\mathrm{CO})(\mathrm{Br})\left(\mathrm{PPh}_{3}\right)\right]$ was prepared following the same procedure as in the case of $\left[\left(\mathrm{L}^{1}\right) \mathrm{Os}(\mathrm{CO})(\mathrm{Br})\left(\mathrm{PPh}_{3}\right)\right]$ using $\mathrm{HL}^{2}$ and $\mathrm{HL}^{3}$ in place of $\mathrm{HL}^{1}$. The solvent used for thin-layer chromatographic separation is toluene-acetonitrile $(95: 5 \mathrm{~V} / \mathrm{V})$ mixed solvent.

Yield: $75 \%$ for $\mathrm{HL}^{2}$ complex $\left[\left(\mathrm{L}^{2}\right) \mathrm{Os}(\mathrm{CO})(\mathrm{Br})\left(\mathrm{PPh}_{3}\right)\right]$. Anal. calc. for 2b. C 53.49, H 3.54, N 4.80. Found C $53.53, \mathrm{H} 3.50, \mathrm{~N} 4.83 \%$. Electronic spectrum $\left(\lambda_{\max } / \mathrm{nm}\right.$ $\left(\varepsilon / \mathrm{dm}^{2} \mathrm{~mol}^{-1}\right)$, dichloromethane): 650 (1300), 470 (4450), 357 (18940), 260 (27370), 232 (45400). IR $\left(\mathrm{KBr}\right.$ pellets, $\left.\mathrm{cm}^{-1}\right): v_{\mathrm{C}=\mathrm{N}} 1604, v_{\mathrm{N}=\mathrm{N}} 1436, v_{\mathrm{CO}} 1920$. ${ }^{1} \mathrm{H}$ NMR $\left(\mathrm{CDCl}_{3} \mathrm{ppm}\right): \delta 8.23(\mathrm{~d}, 2 \mathrm{H}), 7.91(\mathrm{~d}, 1 \mathrm{H})$, $7.62(\mathrm{t}, 6 \mathrm{H}), 7.52-7.28(\mathrm{~m}, 8 \mathrm{H}), 7.15-7.10(\mathrm{~m}, 2 \mathrm{H})$, $7.11(\mathrm{~d}, 1 \mathrm{H}), 6.81(\mathrm{~d}, 1 \mathrm{H}), 6.63(\mathrm{~d}, 1 \mathrm{H}), 6.28(\mathrm{t}, 1 \mathrm{H})$, $2.41(\mathrm{~s}, 3 \mathrm{H}) \mathrm{ppm} . E_{1 / 2}[\mathrm{~V}]\left(\Delta \mathrm{E}_{\mathrm{p}} / \mathrm{mV}\right): 1.12$.

Yield: $70 \%$ for $\mathrm{HL}^{3}$ complex $\left.\left[\left(\mathrm{L}^{3}\right) \mathrm{Os}(\mathrm{CO})(\mathrm{Br})\left(\mathrm{PPh}_{3}\right)\right]\right)$. Anal. calc. for 2c. C 50.93, H 3.12, N 4.69. Found C $51.00, \mathrm{H} 3.15, \mathrm{~N} 4.67 \%$. Electronic spectrum $\left(\lambda_{\max } / \mathrm{nm}\right.$ $\left(\varepsilon / \mathrm{dm}^{2} \mathrm{~mol}^{-1}\right)$, dichloromethane): 650 (1290), 468 (4440), 360 (20331), 256 (29940), 230 (49920). IR $\left(\mathrm{KBr}\right.$ pellets, $\left.\mathrm{cm}^{-1}\right): v_{\mathrm{C}=\mathrm{N}} 1604, v_{\mathrm{N}=\mathrm{N}} 1436, v_{\mathrm{CO}} 1927$. ${ }^{1} \mathrm{H}$ NMR $\left(\mathrm{CDCl}_{3} \mathrm{ppm}\right): \delta 8.30(\mathrm{~d}, 2 \mathrm{H}), 7.92-7.91$ $(\mathrm{m}, 1 \mathrm{H}), 7.78(\mathrm{t}, 6 \mathrm{H}), 7.61(\mathrm{t}, 1 \mathrm{H}), 7.53(\mathrm{~d}, 2 \mathrm{H})$, $7.41(\mathrm{t}, 2 \mathrm{H}), 7.34-7.28(\mathrm{~m}, 8 \mathrm{H}), 7.15(\mathrm{t}, 1 \mathrm{H}), 7.04$ $(\mathrm{s}, 1 \mathrm{H}), 6.81(\mathrm{~d}, 1 \mathrm{H}), 6.64(\mathrm{~d}, 1 \mathrm{H}), 6.46(\mathrm{~d}, 1 \mathrm{H}), 6.29$ $(\mathrm{t}, 1 \mathrm{H}) . E_{1 / 2}[\mathrm{~V}]\left(\Delta \mathrm{E}_{\mathrm{p}} / \mathrm{mV}\right): 1.19$.

2.2e $\left[(L)_{2} \mathrm{Co}_{C} \mathrm{ClO}_{4}\right.$ : The $\left[(\mathrm{L})_{2} \mathrm{Co}\right] \mathrm{ClO}_{4}$ complexes were obtained by following a general procedure. Specific details are given below for a particular complex.

2.2f $\left[\left(L^{1}\right)_{2} \mathrm{Co}_{\mathrm{ClO}_{4}} \quad \mathbf{( 7 a ) :}\right.$ To a solution of $\mathrm{Co}\left(\mathrm{ClO}_{4}\right)_{3} \cdot 6 \mathrm{H}_{2} \mathrm{O}(0.2 \mathrm{~g}, 0.429 \mathrm{mmol})$, in $40 \mathrm{~mL}$ methanol ligand $\mathrm{HL}^{1}(0.5 \mathrm{~g}, 0.428 \mathrm{mmol})$ was added. The mixture was heated to reflux for $1 \mathrm{~h}$. During this time greenish brown solid was precipitated. The solid product was then filtered and washed with water and a little methanol. It was recrystallized from 
dichloromethane-petroleum ether to obtain pure product. Yield: $80 \%$. Anal. calc. for 7a. C 60.07, H 3.68, N 11.06. Found C 60.00, H 3.70, N 11.10\%. Electronic spectrum $\left(\lambda_{\max } / \mathrm{nm}\left(\varepsilon / \mathrm{dm}^{2} \mathrm{~mol}^{-1}\right)\right.$, dichloromethane): 370 (19700), 285 (48200), 230 (41100). IR ( $\mathrm{KBr}$ pellets, $\left.\mathrm{cm}^{-1}\right): v_{\mathrm{C}=\mathrm{N}} 1604, v_{\mathrm{N}=\mathrm{N}} 1436, v_{\mathrm{Cl}-\mathrm{O}} 1083$. ${ }^{1} \mathrm{H}$ NMR $\left(\mathrm{CDCl}_{3} \mathrm{ppm}\right): \delta 8.02(\mathrm{t}, 1 \mathrm{H}), 7.90(\mathrm{~d}, 1 \mathrm{H})$, $7.82-7.79(\mathrm{~m}, 3 \mathrm{H}), 7.49-7.44(\mathrm{~m}, 2 \mathrm{H}), 7.37(\mathrm{~d}, 2 \mathrm{H})$, $7.24-7.18(\mathrm{~m}, 2 \mathrm{H}), 6.71(\mathrm{t}, 1 \mathrm{H}), 6.09(\mathrm{~d}, 1 \mathrm{H}) \mathrm{ppm} . E_{1 / 2}$ [V] $\left(\Delta \mathrm{E}_{\mathrm{p}} / \mathrm{mV}\right):-0.071(116.4), \mathrm{E}\left(\Delta \mathrm{E}_{\mathrm{p}} / \mathrm{mV}\right):-1.60$, -0.85 .

$2.2 \mathrm{~g}$ and $2.2 \mathrm{~h} \quad\left[\left(\mathrm{~L}^{2}\right)_{2} \mathrm{Co}_{\mathrm{ClO}} \mathrm{ClO}_{4}(7 \mathrm{~b})\right.$ and $\left[\left(\mathrm{L}_{\text {sal }}^{3}\right)_{2} \mathrm{Co}\right] \mathrm{ClO}_{4}$ (7c): Complexes $\left[\left(\mathrm{L}^{2}\right)_{2} \mathrm{Co}\right] \mathrm{ClO}_{4}$ and $\left[\left(\mathrm{L}^{3}\right)_{2} \mathrm{Co}_{\mathrm{ClO}}\right.$ were prepared by a similar procedure as described for $\left[\left(\mathrm{L}^{1}\right)_{2} \mathrm{Co}\right] \mathrm{ClO}_{4}$ using ligand $\mathrm{HL}^{2}$ and $\mathrm{HL}^{3}$ in place of $\mathrm{HL}^{1}$.

Yield: $85 \%$. Anal. calc. for 7b. C 60.53, H 3.88, N 10.86. Found C 60.60, H 3.90, N 10.94\%. Electronic spectrum $\left(\lambda_{\max } / \mathrm{nm}\left(\varepsilon / \mathrm{dm}^{2} \mathrm{~mol}^{-1}\right)\right.$, dichloromethane): 390 (21500), 290 (45600), 230 (38600). IR (KBr pellets, $\left.\mathrm{cm}^{-1}\right): v_{\mathrm{C}=\mathrm{N}} 1605, v_{\mathrm{N}=\mathrm{N}} 1433, v_{\mathrm{Cl}-\mathrm{O}} 1089 .{ }^{1} \mathrm{H}$ NMR $\left(\mathrm{CDCl}_{3} \mathrm{ppm}\right): \delta 8.02(\mathrm{t}, 1 \mathrm{H}), 7.87(\mathrm{~d}, 1 \mathrm{H})$, $7.79(\mathrm{~d}, 1 \mathrm{H}), 7.74(\mathrm{t}, 2 \mathrm{H}), 7.34(\mathrm{~d}, 2 \mathrm{H}), 7.29-722$ $(\mathrm{m}, 1 \mathrm{H}), 7.18(\mathrm{~d}, 2 \mathrm{H}), 6.67(\mathrm{t}, 1 \mathrm{H}), 6.06(\mathrm{~d}, 1 \mathrm{H}), 2.42$ $(\mathrm{s}, 3 \mathrm{H}) \mathrm{ppm} . E_{1 / 2}[\mathrm{~V}]\left(\Delta \mathrm{E}_{\mathrm{p}} / \mathrm{mV}\right):-0.081(101.7) . \mathrm{E}$ $\left(\Delta \mathrm{E}_{\mathrm{p}} / \mathrm{mV}\right):-1.55,-1.05$.

Yield: $75 \%$. Anal. calc. for 7c. C 57.45, H 3.40, N 10.58. Found $\mathrm{C} 7.50, \mathrm{H} 3.35, \mathrm{~N} 10.60 \%$. Electronic spectrum $\left(\lambda_{\max } / \mathrm{nm}\left(\varepsilon / \mathrm{dm}^{2} \mathrm{~mol}^{-1}\right)\right.$, dichloromethane): 380 (24950), 285 (52575), 230 (43400). IR (KBr pellets, $\left.\mathrm{cm}^{-1}\right): v_{\mathrm{C}=\mathrm{N}} 1603, v_{\mathrm{N}=\mathrm{N}} 1432, v_{\mathrm{Cl}-\mathrm{O}} 1079 .{ }^{1} \mathrm{H}$ NMR $\left(\mathrm{CDCl}_{3} \mathrm{ppm}\right): \delta 8.34(\mathrm{~d}, 1 \mathrm{H}), 7.78(\mathrm{~d}, 1 \mathrm{H}), 7.34$ $(\mathrm{t}, 2 \mathrm{H}), 7.27-7.23(\mathrm{~m}, 2 \mathrm{H}), 7.16-7.11(\mathrm{~m}, 3 \mathrm{H}), 6.85-$ $6.81(\mathrm{~m}, 2 \mathrm{H}), 6.68(\mathrm{~d}, 1 \mathrm{H}) \mathrm{ppm} . E_{1 / 2}[\mathrm{~V}]\left(\Delta \mathrm{E}_{\mathrm{p}} / \mathrm{mV}\right)$ : -0.063 (122.7), E $\left(\Delta \mathrm{E}_{\mathrm{p}} / \mathrm{mV}\right):-1.50,-0.75$.

\subsection{Physical measurements}

Microanalysis $(\mathrm{C}, \mathrm{H}, \mathrm{N})$ was performed using a Perkin-Elmer $2400 \mathrm{C}, \mathrm{H}, \mathrm{N}, \mathrm{S} / \mathrm{O}$ series II elemental analyzer. Infrared spectra were recorded on a Parkin-Elmer L120-00A FT-IR spectrometer with the samples prepared as $\mathrm{KBr}$ pellets. Electronic spectra were recorded on a Shimadzu UV-1601 PC spectrophotometer. ${ }^{1} \mathrm{H}$ NMR spectra were obtained on Brucker DPX 400 and Brucker 500 RPX NMR spectrometers in $\mathrm{CDCl}_{3}$ using TMS as the internal standard. Electrochemical measurements were made under dinitrogen atmosphere using a PAR model VARSASTAT-II potentiostat. A platinum disc working electrode, a platinum wire auxiliary electrode and an aqueous saturated calomel reference electrode (SCE) were used in a threeelectrode configuration. All electrochemical data were collected at $298 \mathrm{~K}$ and are uncorrected for junction potentials.

\subsection{Transformation of ketones to $2^{0}$ - alcohols via hydrogen transfer reactions}

A mixture containing ketones $(0.050 \mathrm{~g}, 2.8 \mathrm{mmol})$, the osmium complex $(0.0009 \mathrm{~g}, 0.0013 \mathrm{mmol})$ and $(0.0036 \mathrm{~g}, 0.0625 \mathrm{mmol}) \mathrm{KOH}$ was heated to reflux in $10 \mathrm{~mL}$ of i-PrOH for appropriate period of time as mentioned in table 3 . The complex was removed as precipitate from the reaction mixture by the addition of diethyl ether followed by filtration. Subsequent neutralization with $5 \mathrm{~mL}$ of $1(\mathrm{M}) \mathrm{HCl}$ the ether layer was separated and passed through a short path of silica gel. The product was purified by preparative thin-layer chromatography. The yields were calculated after isolation. The hydrogenated products were characterized by matching the UV-Vis, IR and ${ }^{1}$ HNMR spectra of authentic samples.

\subsection{DFT calculations}

Using the $\mathrm{X}$-ray coordinates of the complex $\left[\left(\mathrm{L}^{2}\right) \mathrm{Os}(\mathrm{CO})(\mathrm{Br})\left(\mathrm{PPh}_{3}\right)\right]$ and $\left[\left(\mathrm{L}^{1}\right)_{2} \mathrm{Co}\right] \mathrm{ClO}_{4}$ complex ground state electronic structure calculations have been carried out using DFT ${ }^{46}$ methods with the Gaussian 03 program. ${ }^{47}$ Becke's hybrid function ${ }^{48}$ with the Lee-Yang-Parr (LYP) correlation function ${ }^{49}$ was used throughout the study. We have employed a triple-z quality all-electron basis set (TZP) ${ }^{50}$ for Os and Co. Double-all-electron basis set ${ }^{51}$ for $\mathrm{C}, \mathrm{N}$, and $\mathrm{O}$, and a $6-31 \mathrm{G}$ basis set for H. LANL2DZ valence and effective core potential functions were used. All energy calculations were performed using the self-consistent field 'tight' option of the Gaussian 03 program to ensure sufficiently well-converged values for the state energies.

\section{$2.6 X$-ray crystallographic study}

Single crystals of $\mathbf{2} \mathbf{b}$ and $\mathbf{7 a}$ were grown by slow evaporation of dicholoromethane-acetonitrile mixed solution at $298 \mathrm{~K}$. Data were collected on a Brucker SMART CCD diffractometer using Mo-K $\alpha$ monochromator $(\lambda=0.71073)$. Structure solutions were performed using Shelx 97 PC version program. ${ }^{52}$ Full matrix least square refinements on F2 were performed 
using SHELXL-97 program. ${ }^{53}$ All the non-hydrogen atoms were refined anisotropically using full-matrix least squares method. Hydrogen atoms were included for structure factor calculations after placing them at calculated positions. The data collection parameters and relevant crystal data are collected in table 3 . In table 3 only the cell parameters for $\left[\left(\mathrm{L}^{1}\right)_{2} \mathrm{Co}\right] \mathrm{ClO}_{4}, \mathbf{7 a}$, are shown since it could not be refined well due to the poor quality of data.

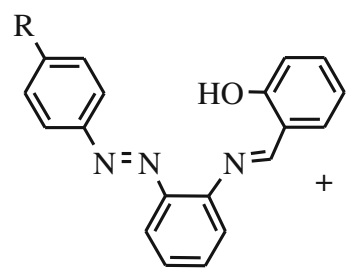

$\mathrm{Os}(\mathrm{H})(\mathrm{CO})(\mathrm{Br})\left(\mathrm{PPh}_{3}\right)_{3}$

\section{Results and discussion}

\subsection{Syntheses}

Reaction of one equivalent $\left[\mathrm{Os}(\mathrm{H})(\mathrm{CO})(\mathrm{Br})\left(\mathrm{PPh}_{3}\right)_{3}\right]$ with two equivalent 1-\{[2-(arylazo)phenyl]iminomethyl $\}$-2phenol, 1, HL, in refluxing toluene afforded olive green $\left[(\mathrm{L}) \mathrm{Os}(\mathrm{CO})(\mathrm{Br})\left(\mathrm{PPh}_{3}\right)\right], \mathbf{2}$, product in $70 \%$ yield after 8 h (Eq. 1).

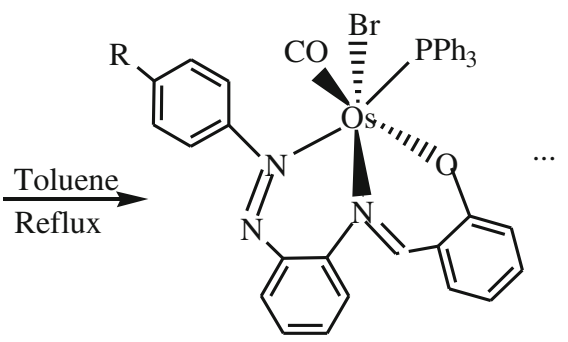

2
Three complexes were prepared using $\mathrm{HL}^{1}, \mathrm{HL}^{2}$ and $\mathrm{HL}^{3}$ which are nonelectrolyte, diamagnetic and soluble in common organic solvents.

In $\left[(\mathrm{L}) \mathrm{Os}(\mathrm{CO})(\mathrm{Br})\left(\mathrm{PPh}_{3}\right)\right]$ complexes deprotonated tridentate $(\mathrm{N}, \mathrm{N}, \mathrm{O})$ donor $\mathrm{L}^{-}$ligands are bound facially and the other three coordination sites are occupied by $\mathrm{CO}, \mathrm{Br}$ and $\mathrm{PPh}_{3}$ (x-ray structure).
Earlier we have reported that the reaction of $\mathrm{HL}$ with $\mathrm{Ru}(\mathrm{H})(\mathrm{CO})\left(\mathrm{PPh}_{3}\right)_{3} \mathrm{Cl}$ substrate afforded both the complexes $\left[(\mathrm{L}) \mathrm{Ru}\left(\mathrm{PPh}_{3}\right)(\mathrm{Cl})(\mathrm{CO})\right], \mathbf{3}$, and $\left[(\mathrm{L})_{2} \mathrm{Ru}\right], \mathbf{4}$, where $(\mathrm{L})^{-}$ligands were bound to the $\mathrm{Ru}(\mathrm{II})$ centre

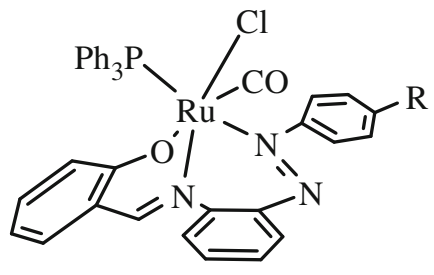

3

$\left[(\mathrm{L}) \mathrm{Ru}(\mathrm{CO})(\mathrm{Cl})\left(\mathrm{PPh}_{3}\right)\right]$

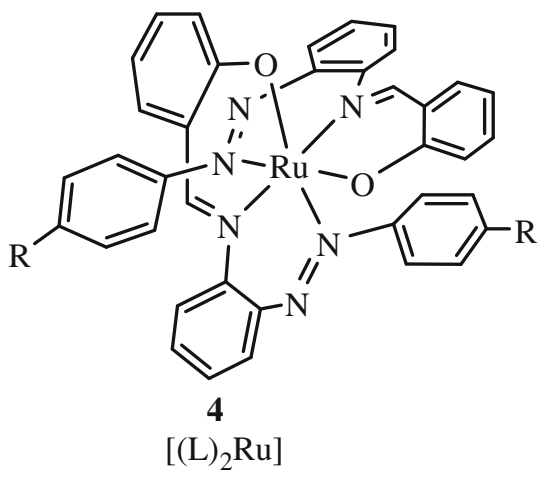

in facial and meridional fashion respectively. ${ }^{41}$ Further, the conversion of $\left[(\mathrm{L}) \mathrm{Ru}\left(\mathrm{PPh}_{3}\right)(\mathrm{Cl})(\mathrm{CO})\right]$ to
$\left[(\mathrm{L})_{2} \mathrm{Ru}\right]$, in the presence of excess free ligand, was also reported but the mechanism of facial to meridional 
amendment of the ligand coordination could not be ascertained. ${ }^{41}$ Whereas, bulkier ligands, 5, afforded only the product 6 upon reaction with same ruthenium substrate. ${ }^{41}$

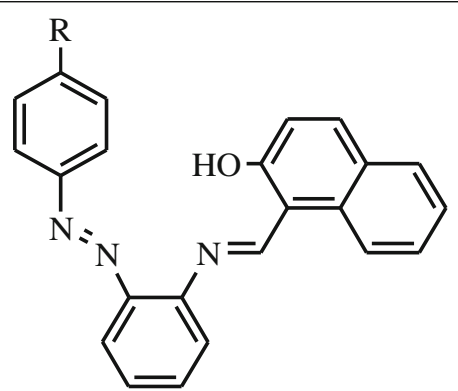

5

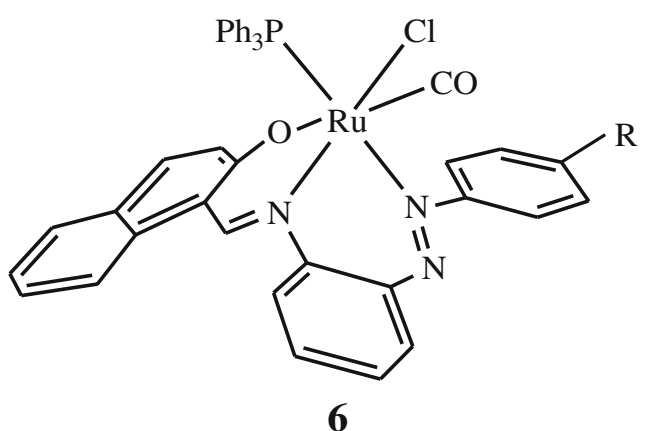

Thus, the fine tuning in the ligand backbone dictated the product in the case of ruthenium substrate. In this paper, we have described that subtle difference in the characteristics of metal ion is also an important factor and can be utilized to prepare the desired product. That is, on going from ruthenium substrates to the osmium substrate $\mathrm{Os}(\mathrm{H})(\mathrm{CO})(\mathrm{Br})\left(\mathrm{PPh}_{3}\right)_{3}$ afforded only $\left[(\mathrm{L}) \mathrm{Os}(\mathrm{CO})(\mathrm{Br})\left(\mathrm{PPh}_{3}\right)\right]$ was isolated without any analogue of $(\mathrm{L})_{2} \mathrm{Ru}$ for both the ligands, 5 and HL. We contemplated to examine the coordination mode of the same ligands in the bis complexes of metal ions that are smaller in size than $\mathrm{Ru}(\mathrm{II})$ and Os(II) with the academic interest to prepare bis complex with facially coordinated ligands. Since $\mathrm{Co}(\mathrm{III})$ is of smaller radii than $\mathrm{Ru}(\mathrm{II})$ and $\mathrm{Os}(\mathrm{II})$ in low spin octahedral geometry so it was chosen. The simple metal substrate $\left[\mathrm{Co}\left(\mathrm{H}_{2} \mathrm{O}\right)_{6}\right] \cdot\left(\mathrm{ClO}_{4}\right)_{3}$ was used for reaction with HL to examine the proposition. Though Os(II) and $\mathrm{Ru}(\mathrm{II})$ are very close in size but Os(II) did not afford the bis complex possibly due to less lability of $\left[(\mathrm{L}) \mathrm{Os}(\mathrm{CO})(\mathrm{Br})\left(\mathrm{PPh}_{3}\right)\right]$ than the ruthenium analogue $\left[(\mathrm{L}) \mathrm{Ru}(\mathrm{CO})(\mathrm{Cl})\left(\mathrm{PPh}_{3}\right)\right]$.

Reaction of two equivalent of HL, 1, with one equivalent of cobalt (III) perchlorate, hexahydrate, $\mathrm{Co}\left(\mathrm{ClO}_{4}\right)_{3} \cdot 6 \mathrm{H}_{2} \mathrm{O}$, in refluxing methanol precipitated the facially coordinated dark coloured crystalline complex $\left[(\mathrm{L})_{2} \mathrm{Co}\right] \mathrm{ClO}_{4}, 7$, which was collected by filtration (Eq. 2). A little more crop of product was isolated upon concentrating the filtrate. In concurrence with our expectation the bis complex of $\mathrm{Co}(\mathrm{III}),\left[(\mathrm{L})_{2} \mathrm{Co}_{\mathrm{ClO}}\right.$, $\mathbf{7}$, is incorporated

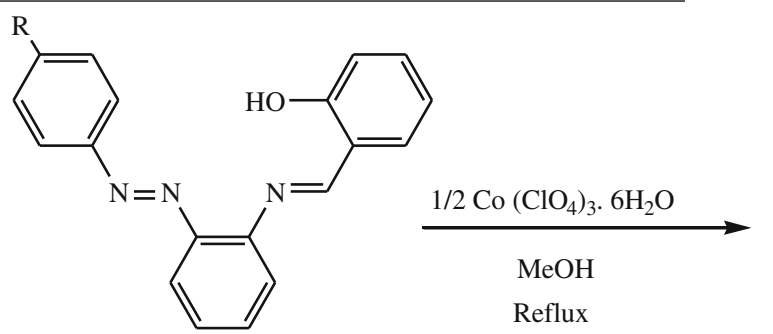

1

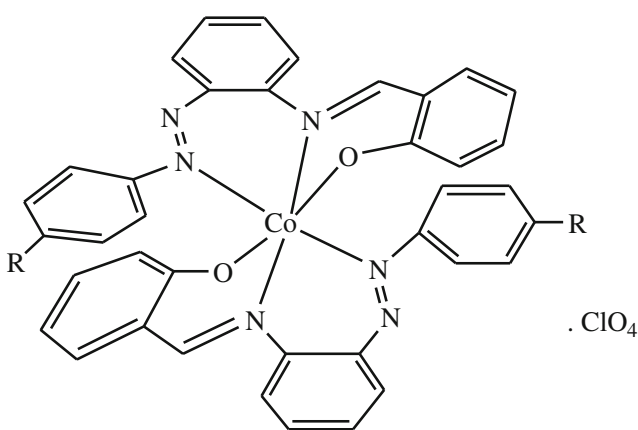

7

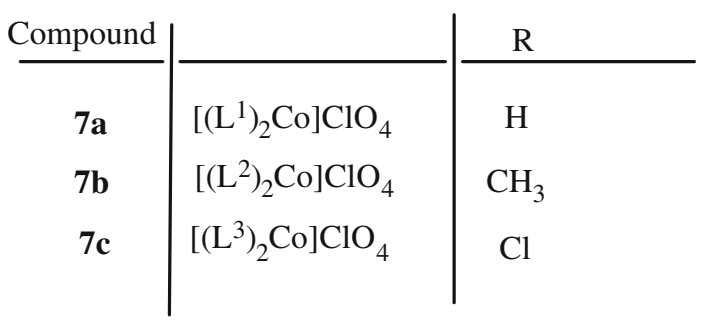

with two facially coordinated tridentate $(\mathrm{N}, \mathrm{N}, \mathrm{O})$ ligands, $\mathrm{L}^{-},(X$-ray structure $)$. The unipositive charge of the complex cation, $\left[(\mathrm{L})_{2} \mathrm{Co}\right]^{+}, 7$, was satisfied by one $\mathrm{ClO}_{4}^{-}$ion. These complexes are soluble in common 
organic solvent and the colour of the solution is greenish brown. The complex is 1:1 electrolyte in acetonitrile solution and diamagnetic signifying the low spin $\mathrm{d}^{6}$ configuration in octahedral ligand field. The composition of diamagnetic $\left[(\mathrm{L})_{2} \mathrm{Co}\right] \mathrm{ClO}_{4}$ complexes matched well with the analytical data and total proton count in ${ }^{1} \mathrm{H}$ NMR spectrum (vide infra).

\subsection{Characterization}

The green solutions of $\left[(\mathrm{L}) \mathrm{Os}(\mathrm{CO})(\mathrm{Br})\left(\mathrm{PPh}_{3}\right)\right]$ complexes in dichloromethane display characteristic UVVis spectra where a low energy absorption near $655 \mathrm{~nm}$ is diagnostic of $\mathrm{d}-\mathrm{d}$ transition. Spectral data are collated in experimental section.

The UV-Vis spectra of the greenish brown solutions of $\left[(\mathrm{L})_{2} \mathrm{Co}\right] \mathrm{ClO}_{4}$ in $\mathrm{CH}_{2} \mathrm{Cl}_{2}$ feature a relatively weak absorption band near $670 \mathrm{~nm}$ for $\mathrm{d}-\mathrm{d}$ transition. ${ }^{45,54}$ The $\left[(\mathrm{L})_{2} \mathrm{Co}\right] \mathrm{ClO}_{4}$ complexes show a weak absorption band near $375 \mathrm{~nm}$. A representative spectrum of $\left[\left(\mathrm{L}^{1}\right)_{2} \mathrm{Co}\right] \mathrm{ClO}_{4}$ is shown in figure 1 . The UV-Vis spectral data are given in the experimental section. All the UV-Vis spectra are given in supplementary material (figures S1-S6).

IR spectra of all the complexes were recorded in solid $\mathrm{KBr}$ support. The spectra displayed $v_{\mathrm{C}=\mathrm{N}}$ for $\left[(\mathrm{L}) \mathrm{Os}(\mathrm{CO})(\mathrm{Br})\left(\mathrm{PPh}_{3}\right)\right]$ and $\left[(\mathrm{L})_{2} \mathrm{Co}\right] \mathrm{ClO}_{4}$ near 1604 and $1603 \mathrm{~cm}^{-1}$, respectively. The $v_{\mathrm{N}=\mathrm{N}}$ $\left(\left[(\mathrm{L}) \mathrm{Os}(\mathrm{CO})(\mathrm{Br})\left(\mathrm{PPh}_{3}\right)\right]\right.$ and $\left[(\mathrm{L})_{2} \mathrm{Co}\right] \mathrm{ClO}_{4}$, appeared near 1434 and $1435 \mathrm{~cm}^{-1}$, respectively. These stretching frequencies are of lower energy than the corresponding ligand characteristics $\left(v_{\mathrm{C}=\mathrm{N}}, \sim 1615 \mathrm{~cm}^{-1}\right.$

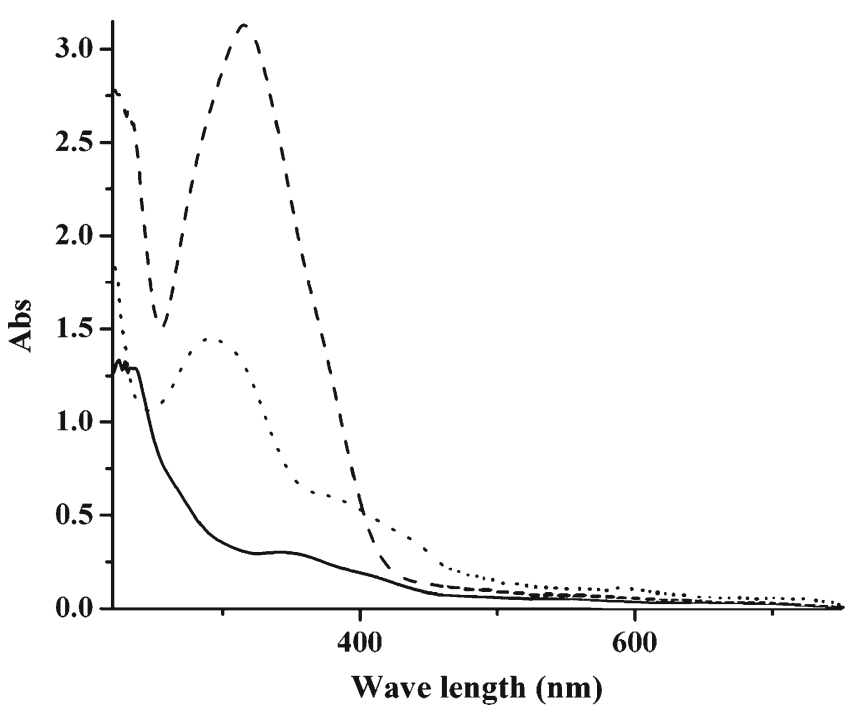

Figure 1. UV-Vis spectra of 1a (- - ), 2a(-) and $7 \mathbf{a}(\cdots)$. and $v_{\mathrm{N}=\mathrm{N}} 1456 \mathrm{~cm}^{-1}$ ) signifying the coordination of aldimino $(-\mathrm{CH}=\mathrm{N}-)$ and azo $(-\mathrm{N}=\mathrm{N}-)$ nitrogens. ${ }^{55-57}$ The $v_{\mathrm{CO}}$ appeared near $1920 \mathrm{~cm}^{-1}$ for $\left(\left[(\mathrm{L}) \mathrm{Os}(\mathrm{CO})(\mathrm{Br})\left(\mathrm{PPh}_{3}\right)\right]\right.$ complexes. A broad band appeared near $1080 \mathrm{~cm}^{-1}$, which is the characteristic of uncoordinated $\mathrm{ClO}_{4}^{-}$for $\left[(\mathrm{L})_{2} \mathrm{Co}\right] \mathrm{ClO}_{4}$. The IR data are collected in experimental section. The IR spectra of the complexes are shown in supplementary materials (figures S7-S12).

The ${ }^{1} \mathrm{H}-\mathrm{NMR}$ spectral pattern matched well with the composition of $\left[(\mathrm{L}) \mathrm{Os}(\mathrm{CO})(\mathrm{Br})\left(\mathrm{PPh}_{3}\right)\right]$ and $\left[(\mathrm{L})_{2} \mathrm{Co}\right] \mathrm{ClO}_{4}$. The ${ }^{1} \mathrm{H}-\mathrm{NMR}$ spectra of $\left[(\mathrm{L}) \mathrm{Os}(\mathrm{CO})(\mathrm{Br})\left(\mathrm{PPh}_{3}\right)\right]$ complexes were recorded in $\mathrm{CDCl}_{3}$. The ${ }^{1} \mathrm{H}-\mathrm{NMR}$ data are collected in experimental section. Absence of phenolic $\mathrm{OH}$ signal indicated the coordination of phenoxide oxygen for all the complexes. ${ }^{41,56,57}$ The upfield shift of aldimine protons (appeared near $\sim \delta 7.10$ as a singlet for $\left.\left[(\mathrm{L}) \mathrm{Os}(\mathrm{CO})(\mathrm{Br})\left(\mathrm{PPh}_{3}\right)\right]\right)$ than the ligands $(\sim \delta$ 8.55) were observed for all the complexes consistent with the imine coordination. ${ }^{55-57}$ All other aromatic proton resonances appeared within $\sim \delta 8.51-\delta 6.28$ for $\left[(\mathrm{L}) \mathrm{Os}(\mathrm{CO})(\mathrm{Br})\left(\mathrm{PPh}_{3}\right)\right]$. The fifteen protons of $\mathrm{PPh}_{3}$ appear as two multiplets within the range $\delta 7.53-\delta 7.44$ for six protons and $\delta 7.32-\delta 7.25$ for nine protons. The aldimine and aromatic protons for $\left[(\mathrm{L})_{2} \mathrm{Co}\right] \mathrm{ClO}_{4} \mathrm{did}$ not resolve well due to overlapping signals. The $-\mathrm{CH}_{3}$ protons signal appears at $\delta 2.42$ for $\left[\left(\mathrm{L}^{2}\right)_{2} \mathrm{Co}\right] \mathrm{ClO}_{4}$. The ${ }^{1} \mathrm{H}-\mathrm{NMR}$ spectra of $\left[(\mathrm{L}) \mathrm{Os}(\mathrm{CO})(\mathrm{Br})\left(\mathrm{PPh}_{3}\right)\right]$ and $\left[(\mathrm{L})_{2} \mathrm{Co}\right] \mathrm{ClO}_{4}$ complexes are given in supplementary materials (figures S13-S18).

\section{$3.3 X$-ray structure}

Single crystals of $\left[\left(\mathrm{L}^{2}\right) \mathrm{Os}(\mathrm{CO})(\mathrm{Br})\left(\mathrm{PPh}_{3}\right)\right]$ was grown by slow evaporation of dichloromethane and acetonitrile mixed solvents. Suitable crystals were picked for $\mathrm{X}$-ray studies. A perspective view of the molecule has been shown in figure 2 and selected bond distances and angles are collected in table 1.

The asymmetric unit of $\left[\left(\mathrm{L}^{2}\right) \mathrm{Os}(\mathrm{CO})(\mathrm{Br})\left(\mathrm{PPh}_{3}\right)\right]$ contains two molecules. The geometry and bond parameters are similar for both the molecules. The molecular structure of each monomer molecule exhibit octahedral coordination with facial geometry about Os, where the monoanionic ligand, $\left(\mathrm{L}^{2}\right)^{-}$, binds the metal in tridentate $(\mathrm{N}, \mathrm{N}, \mathrm{O})$ fashion. The other three ligands, $\mathrm{Br}, \mathrm{CO}$ and $\mathrm{PPh}_{3}$ complete the hexacoordination about

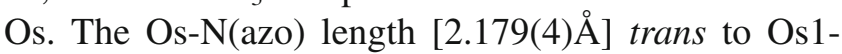
$\mathrm{P} 1[2.33387(15) \AA]$ is longer than the Os1-N3(aldimine) length $[2.037(16) \AA]$ which is trans to Os1-Br1 [2.5620(6) $\AA]$. The N(1)-N(2) length [1.273(6) $\AA]$ in 


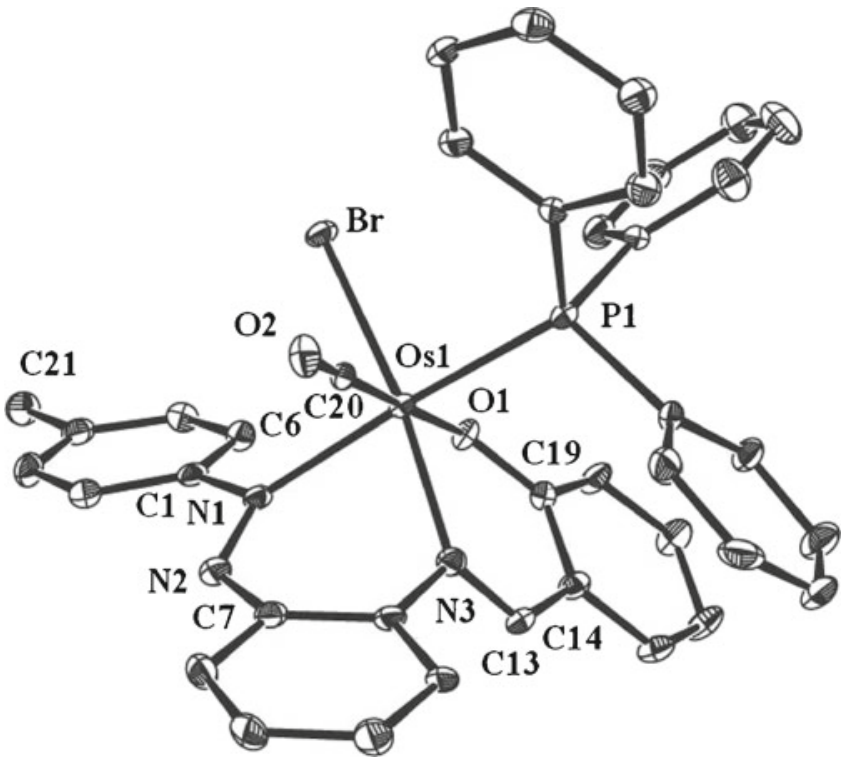

Figure 2. Perspective view (30\% probability ellipsoids) of $\mathbf{2 b}$, with atom numbering scheme. The hydrogen atoms have been omitted for clarity.

the coordinated azo function is shorter than other Os(II) azo complexes. ${ }^{37-41}$ The Os1 -P1 distance is longer than other reported Os-P distances. ${ }^{40,41}$

Crystals of $\left[\left(\mathrm{L}^{1}\right)_{2} \mathrm{Co}\right] \mathrm{ClO}_{4}, 7 \mathbf{a}$, were grown by slow diffusion of dichloromethane solution into petroleum ether. A perspective (ball stick) view of the molecule has been shown in figure 3. The asymmetric unit of $\left[\left(\mathrm{L}^{1}\right)_{2} \mathrm{Co}\right] \mathrm{ClO}_{4}$ contains two molecules.

Table 1. Selected bond distances $(\AA)$ and angles $\left({ }^{\circ}\right)$ for compound $\mathbf{2 b}$.

\begin{tabular}{|c|c|c|c|}
\hline \multirow[b]{2}{*}{ Distances $(\AA)$} & \multicolumn{3}{|c|}{$\left[\left(\mathrm{L}^{2}\right) \mathrm{Os}(\mathrm{CO})(\mathrm{Br})\left(\mathrm{PPh}_{3}\right)\right]$} \\
\hline & & & \\
\hline Os1-Br & $2.5620(6)$ & Os1-C20 & $1.834(6)$ \\
\hline Os1-P1 & $2.3387(15)$ & $\mathrm{N} 1-\mathrm{N} 2$ & $1.273(6)$ \\
\hline Os1-O1 & $2.091(4)$ & $\mathrm{N} 1-\mathrm{C} 1$ & $1.440(7)$ \\
\hline Os1-N1 & $2.179(4)$ & $\mathrm{N} 2-\mathrm{C} 7$ & $1.423(7)$ \\
\hline Os1-N3 & $2.037(5)$ & N3-C12 & $1.431(7)$ \\
\hline N3-C13 & $1.309(7)$ & O1-C19 & $1.315(7)$ \\
\hline \multicolumn{4}{|l|}{ Angles $\left({ }^{\circ}\right)$} \\
\hline Br-Os1-P1 & $92.77(4)$ & N3-Os1-C20 & $94.5(2)$ \\
\hline Br-Os1-O1 & $88.34(10)$ & Os1-O1-C19 & $126.4(3)$ \\
\hline Br-Os1-N1 & $91.78(12)$ & N2-N1-C1 & $111.5(4)$ \\
\hline Br-Os1-N3 & $168.79(14)$ & Os1-N1-N2 & $122.5(4)$ \\
\hline Br-Os1-C20 & $91.54(17)$ & Os1-N1-C1 & $125.5(4)$ \\
\hline N1-Os1-N3 & $78.88(17)$ & $\mathrm{N} 1-\mathrm{N} 2-\mathrm{C} 7$ & $121.2(5)$ \\
\hline N1-Os1-C20 & $89.3(2)$ & Os1-N3-C12 & $114.5(3)$ \\
\hline Os1-N3-C13 & $128.7(4)$ & C12-N3-C13 & $116.4(5)$ \\
\hline
\end{tabular}

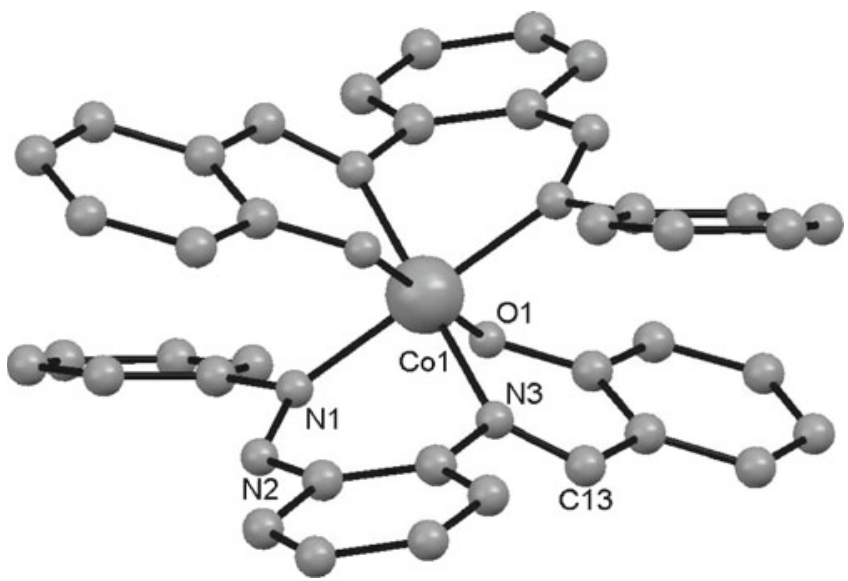

Figure 3. Perspective (ball stick) view of 7a, (except $\left.\mathrm{ClO}_{4}\right)^{-}$with atom numbering scheme. The hydrogen atoms have been omitted for clarity.

The molecular structure exhibits octahedral coordination about $\mathrm{Co}(\mathrm{III})$, where the two anionic ligand, $\left(\mathrm{L}^{1}\right)^{-}$, coordinated facially as tridentate $\mathrm{N}, \mathrm{N}, \mathrm{O}$ donor through phenoxide- $\mathrm{O}$, azo nitrogen and aldimino nitrogen. Each ligand binds the metal forming two sixmembered chelate ring. A perchlorate $\left(\mathrm{ClO}_{4}\right)^{-}$ion satisfied the unipositive charge of the complex cation, $\left[\left(\mathrm{L}^{1}\right)_{2} \mathrm{Co}\right]^{+}$. The relative orientations of donor atoms (azo $\mathrm{N}$, imine $\mathrm{N}$, and phenoxide $\mathrm{O}$ ) of two ligands are trans, trans and trans, respectively. The $\mathrm{X}$-ray structure of $\left[\left(\mathrm{L}^{1}\right)_{2} \mathrm{Co}\right] \mathrm{ClO}_{4}$ could not be refined well due to poor quality of data. Although the refinement was poor but the facial coordination modes of the ligands could be recognized.

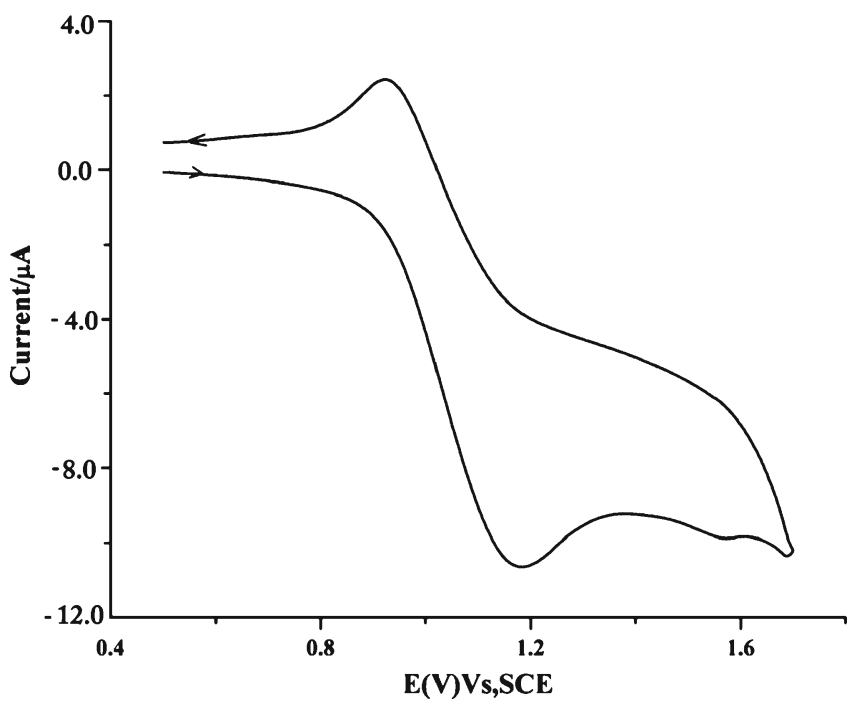

Figure 4. Cyclic voltammogram of the $\mathbf{2 b}$ complex in dichloromethane solution $(0.1 \mathrm{M}$ TBAP) at scan rate of $50 \mathrm{mV} \mathrm{s}^{-1}$. 


\subsection{Electrochemistry}

$\left[(\mathrm{L}) \mathrm{Os}(\mathrm{CO})(\mathrm{Br})\left(\mathrm{PPh}_{3}\right)\right]$ complexes exhibit an one electron reversible oxidative cyclic voltammetric response near $1.0 \mathrm{~V}$ in dichloromethane solution. The oxidation has been assigned according to the couple of Eq. (3), where $\left[(\mathrm{L}) \mathrm{Os}(\mathrm{CO})(\mathrm{Br})\left(\mathrm{PPh}_{3}\right)\right]^{+}$is the Os(III) analogue of $\left[(\mathrm{L}) \mathrm{Os}(\mathrm{CO})(\mathrm{Br})\left(\mathrm{PPh}_{3}\right)\right]$.

$$
\left[(\mathrm{L}) \mathrm{Os}(\mathrm{Br})(\mathrm{CO})\left(\mathrm{PPh}_{3}\right)\right]-\mathrm{e} \longrightarrow \quad\left[(\mathrm{L}) \mathrm{Os}(\mathrm{Br})(\mathrm{CO})\left(\mathrm{PPh}_{3}\right)\right]^{+}
$$

Representative cyclic voltammograms of $\left[\left(\mathrm{L}^{2}\right) \mathrm{Os}(\mathrm{CO})(\mathrm{Br})\left(\mathrm{PPh}_{3}\right)\right]$ has been shown in figure 4 and all other cyclic viltammograms were given in supplementary material (figures S19-S21).

To gain insight into the redox orbitals, single point DFT calculations were performed using the crystallographic coordinates of $\left[\left(\mathrm{L}^{2}\right) \mathrm{Os}(\mathrm{CO})(\mathrm{Br})\left(\mathrm{PPh}_{3}\right)\right]$. Two frontier orbitals HOMO and LUMO are shown in figure $5 \mathrm{a}$ and $\mathrm{b}$. From the DFT results, it appears that the HOMO has considerable metal character, whereas the LUMO is essentially ligand centred. Therefore, on the basis of DFT result, the oxidative couple may be inferred to be due to the metal centred Os(II)/Os(III) redox couple signifying accessibility to variable redox levels of metal.

The $\left[(\mathrm{L})_{2} \mathrm{Co}\right] \mathrm{ClO}_{4}$ Complexes exhibit a one electron reversible reductive cyclic voltammetric response in the range of -0.06 to $-0.12 \mathrm{~V}$ vs SCE and two irreversible reductive responses within $-0.75 \mathrm{~V}$ to $-1.62 \mathrm{~V}$ vs SCE in dichloromethane solution. A representative cyclic voltammogram of $\left[\left(\mathrm{L}^{1}\right)_{2} \mathrm{Co}\right] \mathrm{ClO}_{4}$ is shown in figure 6 and other data are given in experimental section. To gain insight into the redox orbitals of the cobalt complexes, DFT restricted single point
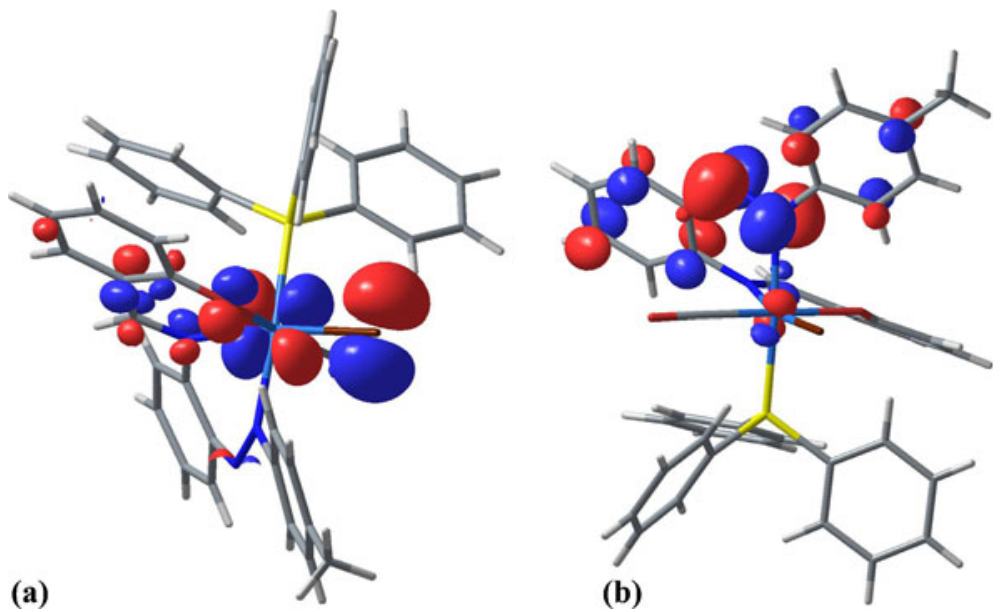

Figure 5. (a) HOMO of $\mathbf{2 b}$ and (b) LUMO of $\mathbf{2 b}$.
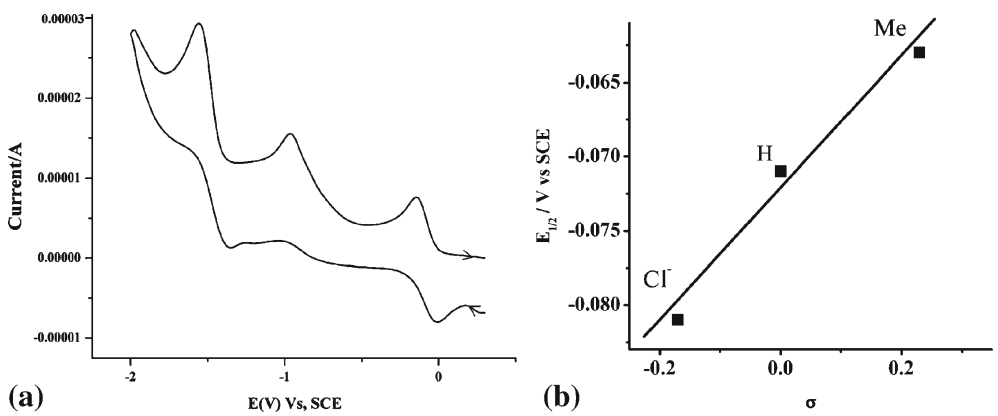

Figure 6. (a) Cyclic voltammogram of the 7a complex in dichloromethane solution $\left(0.1 \mathrm{M}\right.$ TBAP) at scan rate of $50 \mathrm{mV} \mathrm{s}^{-1}$. (b) A least-squares plot of $E_{1 / 2}$ values of $7 \mathbf{a}$ complexes vs. $\sigma$ (Hammett substituent constant). 

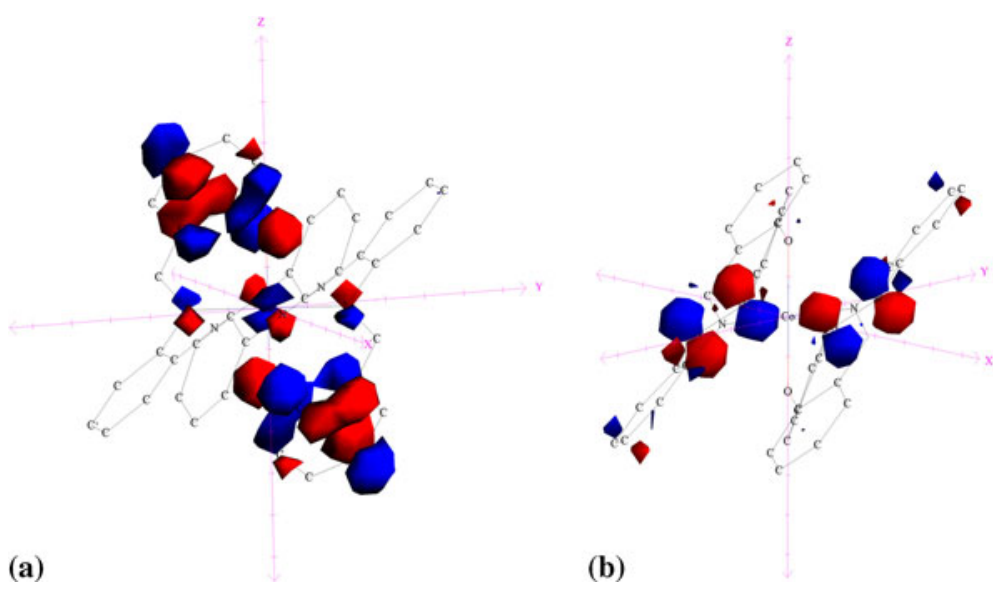

Figure 7. (a) HOMO of $\mathbf{7 a}$ and (b) LUMO of $\mathbf{7 b}$.

calculations were performed were carried out on $\left[\left(\mathrm{L}^{1}\right)_{2} \mathrm{Co}\right]^{+}$moiety using the crystallographic coordinates. Plot of HOMO and LUMO are shown in figure 7a and $b$. Although HOMO has considerable metal character but LUMO is ligand centred. As a result, reductive responses of $\left[(\mathrm{L})_{2} \mathrm{Co}\right] \mathrm{ClO}_{4}$ are attributed to ligand centred reductions. Plot of $\mathrm{E}_{1 / 2}$ values of $\left[(\mathrm{L})_{2} \mathrm{Co}\right] \mathrm{ClO}_{4}$, within $-0.06-0.12 \mathrm{~V}$ Vs SCE, against Hamett constants of $-\mathrm{CH}_{3},-\mathrm{Cl}$ and $-\mathrm{H}$ is linear indicating the ligand contribution in redox orbital.

\subsection{Transformation of ketones to $2^{0}$ - alcohols via hydrogen transfer reactions}

Hydrogenation of organic molecules in homogenous media by means of catalytic transfer hydrogen process has received attention in recent years. ${ }^{57-59}$ Several platinum metal complexes have been used as catalyst for the reductive conversion of ketones to $2^{0}$ - alcohols. ${ }^{60-63}$ To the best of our knowledge, use of Os(II) complexes as transfer hydrogen catalyst have not been studied considerably. ${ }^{64-66}$ Therefore, we were encouraged to examine the catalytic activity of $\left[\left(\mathrm{L}^{1}\right) \mathrm{Os}(\mathrm{CO})(\mathrm{Br})\left(\mathrm{PPh}_{3}\right)\right]$, toward transfer hydrogenation of representative aliphatic and aromatic ketones. The conversion of ketones to corresponding alcohols were studied in 2-propanol adding catalytic amount of $\left[\left(\mathrm{L}^{1}\right) \mathrm{Os}(\mathrm{CO})(\mathrm{Br})\left(\mathrm{PPh}_{3}\right)\right]$ and $\mathrm{KOH}$ in the reaction mixture as given in Eq. (4). The results of transformations are listed in table 2 .

After the catalytic reactions neither the original complex, $\left[\left(\mathrm{L}^{1}\right) \mathrm{Os}(\mathrm{CO})(\mathrm{Br})\left(\mathrm{PPh}_{3}\right)\right]$, nor the transformed

Table 2. Transformation of ketones to $2^{0}$ - alcohols via hydrogen transfer reactions for $2 \mathbf{a}$.

Entry Substrate


Table 3. Crystallographic data for $\mathbf{2 b}$ and $\mathbf{7 a}$.

\begin{tabular}{lll}
\hline & $\mathbf{2 b}$ & $\mathbf{7 a}$ \\
\hline Chemical formula & $\mathrm{C}_{39} \mathrm{H}_{31} \mathrm{BrN}_{3} \mathrm{O}_{2} \mathrm{OsP}$ & $\mathrm{C}_{38} \mathrm{H}_{28} \mathrm{CoN}_{6} \mathrm{O}_{2}, \mathrm{ClO}_{4}$ \\
Formula weight & 874.77 & 759.11 \\
Crystal system & Monoclinic & Triclinic \\
Space group & $\mathrm{P} 21$ & $\mathrm{P}-1$ \\
$A[\AA]$ & $9.10100(10)$ & $10.6348(5)$ \\
$B[\AA]$ & $18.0120(2)$ & $13.7687(6)$ \\
$C[\AA]$ & $20.8460(2)$ & $14.5032(5)$ \\
$\alpha\left[^{\circ}\right]$ & 90 & $86.013(2)$ \\
$\beta\left[^{\circ}\right]$ & $89.8550(10)$ & $69.330(2)$ \\
$\gamma\left[{ }^{\circ}\right]$ & 90 & $78.255(2)$ \\
$\lambda[\AA]$ & 0.71073 & 0.71073 \\
$V\left[\AA^{3}\right]$ & $3417.22(6)$ & $1945.36(14)$ \\
$F(000)$ & 1712 & 864 \\
$Z$ & 4 & 2 \\
$T / \mathrm{K}$ & 150 & 273 \\
$D / \mathrm{g} / \mathrm{cm}^{3}$ & 1.700 & - \\
$\mu / \mathrm{mm}^{-1}$ & 4.987 & - \\
$R I($ all data $)$ & 0.0396 & - \\
$w R 2[I>2 \sigma(I)]$ & 0.0773 & - \\
$G O F$ & 1.00 & - \\
\hline
\end{tabular}

complex could be isolated and identified indicating the fact that the possibility of $\left[\left(\mathrm{L}^{1}\right) \mathrm{Os}(\mathrm{CO})(\mathrm{Br})\left(\mathrm{PPh}_{3}\right)\right]$ complex to be a precatalyst can not be ruled out.
Notably, similar Ru complexes, reported earlier, ${ }^{41}$ did not exhibit the catalytic activity for such transfer hydrogen reactions.

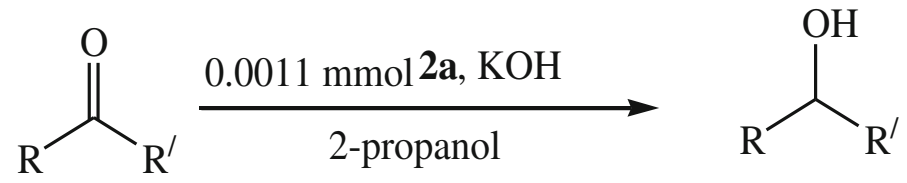

All the reactions were carried out in ambient condition. A series of blank reactions were carried out in the absence of complex $\left[\left(\mathrm{L}^{1}\right) \mathrm{Os}(\mathrm{CO})(\mathrm{Br})\left(\mathrm{PPh}_{3}\right)\right]$. This has ascertained the necessity of the complex during the reaction. The yields of the alcohols obtained from all the ketones were determined after isolation (table 3 ).

\section{Concluding remarks}

Reaction of tridentate N,N,O donor ligand $\mathrm{HL}$ with $\mathrm{Os}(\mathrm{H})(\mathrm{CO})(\mathrm{Br})\left(\mathrm{PPh}_{3}\right)_{3}$ afforded new face capped complexes of Os(II). The new face capped $\left[(\mathrm{L}) \mathrm{Os}(\mathrm{CO})(\mathrm{Br})\left(\mathrm{PPh}_{3}\right)\right]$ complexes exhibit an one electron reversible oxidative cyclic voltammetric response near $1.0 \mathrm{~V}$ in dichloromethane solution. The new Os(II) complexes are catalytically active toward transfer hydrogen catalysis. Reaction of HL with $\mathrm{Co}\left(\mathrm{H}_{2} \mathrm{O}\right)_{6}$. $\left(\mathrm{ClO}_{4}\right)_{3}$ afforded bis complex where both the ligands are facially coordinated unlike the bis complex of $\mathrm{Ru}(\mathrm{II})$, where both the ligands are meridionally bound. Reversible accessibility to the different redox states for $\left[(\mathrm{L})_{2} \mathrm{Co}\right] \mathrm{ClO}_{4}$ have been attributed to ligand centred electron transfer processes according to the DFT calculations.

\section{Supplementary data}

Figures S1-S6 shows the UV-Vis spectra, figures S7S12 show the IR spectra, figures $\mathrm{S} 13-\mathrm{S} 18$ the ${ }^{1} \mathrm{H}$ NMR spectra and figures S19-S24 show the cyclic voltammogram of all the complexes (these supplementary figures S1-S6 can be seen in www.ias.ac.in/ chemsci.website). CCDC-764971 for $\mathbf{2 b}$ and CCDC808866 for 7a contain the supplementary crystallographic data for this paper. These data can be obtained free of charge from the Cambridge Crystallographic Data Centre, 12 Union Road, Cambridge CB21EZ, UK; fax: (+44)1223-336-033; or e-mail: deposite@ccdc.cam.ac.uk. 


\section{Acknowledgements}

Authors thank the Department of Science and Technology (DST) (New Delhi) for funding under DSTSERC (SR/S1/IC-0026/2007) project. The necessary laboratory and infrastructural facility are provided by the Department of Chemistry, University of Kalyani. The support of DST under FIST and the University Grants Communication (UGC) SAP program to the Department of Chemistry, University of Kalyani is also acknowledged.

\section{References}

1. Zhang J, Braunstein P and Andy Hor T S 2008 Organometallics 274277

2. Young C G, Malarek M S, Evans D J, Doonan C J, Wee Lin Ng V and White J M 2009 Inorg. Chem. 481960

3. Poyatos M, Mata J A and Peris E 2009 Chem. Rev. 109 3677

4. Liang L-C, Cheng L-C, Tsai T-L, Hu C-H and Guo W-H 2009 Inorg. Chem. 485697

5. Mattsson J, Govindaswamy P, Renfrew A K, Dyson P J, Stepnitka P, Sqss-Fink G and Therrien B 2009 Organometallics $\mathbf{2 8} 4350$

6. Traar P, Schröckeneder A, Judmaier M E, Belaj F, Baumgartner J, Sachse A and Mösch-Zanetti N C 2010 Eur. J. Inorg. Chem. 5718

7. Dougan S J, Habtemariam A, McHale S E, Parsons S and Sadler P J 2008 Proc. Natl. Acad. Sci. USA 105 11628

8. Poyatos M, Mata J A and Peris E 2009 Chem. Rev. 109 3677

9. Singh P and Singh A K 2010 Eur. J. Inorg. Chem. 4187

10. Peacock A F A, Habtemariam A, Fernandez R, Walland V, Fabbiani F P A, Parsons S, Aird R E, Jodrell D I and Sadler P J 2006 J. Am. Chem. Soc. 1281739

11. Wirth S, Rohbogner C J, Cieslak M, KazmierczakBaranska J, Donevski S, Nawrot B and Lorenz I P 2010 J. Biol. Inorg. Chem. 15429

12. Boardman B, Hanton M J, Rensburg H V and Tooze R P 2006 Chem. Commun. 2289

13. van Engelen M C, Teunissen H T, De Vries J G and Elsevier C J 2003 J. Mol. Catal. A: Chem. 206185

14. Yin A Y, Guo X Y, Dai W-L and Fan K N 2010 Chem. Commun. 464348

15. Therrien B 2009 Coord. Chem. Rev. 253493

16. Sarfraz R A, Kazia T G, Iqbalb S, Afridia H I, Jamali M K, Jalbani N and Arain M B 2008 Appl. Organometal. Chem. 22187

17. Matteoli U, Menchi G, Bianchi M and Piacenti F 1988 J. Mol. Catal. 44347

18. Matteoli U, Menchi G, Bianchi M, Piacenti F, Ianelli S and Nardelli M 1995 J. Organomet. Chem. 498177

19. Matteoli U, Menchi G, Bianchi M and Piacenti F 1991 J. Mol. Catal. 64257

20. Nomura K, Ogura H and Imanishi Y 2001 J. Mol. Catal. A: Chem. 166345

21. Nomura K, Ogura H and Imanishi Y 2002 J. Mol. Catal. A: Chem. 178105
22. Chaudhuri P and Wieghardt K 1987 Prog. Inorg. Chem. 35329

23. Blake A J and Schröder M 1990 Adv. Inorg. Chem. 351

24. Spicer M D and Reglinski J 2009 Eur. J. Inorg. Chem. 1553

25. Iengo E, Zangrando E, Baiutti E, Munini F and Alessio E 2005 Eur. J. Inorg. Chem. 1019

26. St.-J. Foreman M R, Hill A F, Owen G R, White A J P and Williams D J 2003 Organometallics 224446

27. Garcia R, Paulo A and Santos I 2009 Inorg. Chim. Acta. 3624315

28. Harding D J, Harding P, Kivnang J and Adams H 2010 Transition Met. Chem. 35521

29. Trofimenko S 1993 Chem. Rev. 93943

30. Borguet Y, Sauvage X, Zaragoza G, Demonceau A and Delaude L 2010 Organometallics 296675

31. Wang X-Y, Shi H-T, Wu F-H and Zhang Q-F 2010 J. Mol. Struct. 98266

32. Trofimenko S 1986 Prog. Inorg. Chem. 34115

33. Walker J M, Cox A M, Wang R and Spivak G J 2010 Organometallics 296121

34. Therrien B, Vieille-Petit L and Süss-Fink G 2005 J. Mol. Struct. 738161

35. Puerta M C and Valerga P 1999 Coord. Chem. Rev. 193 977

36. Das C, Peng S-M, Lee G-H and Goswami S 2002 New J. Chem. 26222

37. Acharyya R, Peng S-M, Lee G-H and Bhattacharya S 2003 Inorg. Chem. 427378

38. Gupta P, Butcher R J and Bhattacharya S 2003 Inorg. Chem. 425405

39. Majumder K, Peng S M and Bhattacharya S $2001 \mathrm{~J}$. Chem. Soc. Dalton Trans. 284

40. Pratihar J L, Pattanayak P, Bhaduri S, Patra D and Chattopadhyay S 2010 J. Chem. Res. 98

41. Pattanayak P, Pratihar J L, Patra D, Burrows A, Mohan M and Chattopadhyay S 2010 Inorg. Chim. Acta 363 2865

42. Perrin D D and Armarego W L F 1988 Purification of laboratory chemicals, 3rd edn.; New York: Pergamon

43. Parshall G W 1974 Inorg. Synth. XV 48 and 50

44. Trost B M and Verhoeven T R 1982 in: Comprehensive organometallic chemistry, E Abel, F G A Stone, G Wilkinson (Eds.), vol. 8; Oxford: Pergamon Press

45. Pattanayak P, Pratihar J L, Patra D, Burrows A, Mohan M and Chattopadhyay S 2007 Eur. J. Inorg. Chem. 4263

46. Parr R G and Yang W 1989 Density functional theory of atoms and molecules; Oxford: Oxford University Press

47. Frisch M J, Trucks G W, Schlegel H B, Scuseria G E, Robb M A, Cheeseman Jr J R, Montgomery J A, Vreven T, Kudin K N, Burant J C, Millam J M, Iyengar S S, Tomasi J, Barone V, Mennucci B, Cossi M, Scalmani G, Rega N, Petersson G A, Nakatsuji H, Hada M, Ehara M, Toyota K, Fukuda R, Hasegawa J, Ishida M, Nakajima T, Honda Y, Kitao O, Nakai H, Klene M, Li X, Knox J E, Hratchian H P, Cross J B, ammi R, Pomelli C, Ochterski J W, Ayala P Y, Morokuma K, Voth G A, Salvador P, Dannenberg J J, Zakrzewski V G, Dapprich S, Daniels A D, Strain M C, Farkas O, Malick D K, Rabuck A D, Raghavachari K, Foresman J B, Ortiz J V, Cui Q, Baboul A G, Clifford S, Cioslowski J, 
Stefanov B B, Liu G, Liashenko A, Piskorz P, Komaromi I, Martin R L, Fox D J, Keith T, Al-Laham A, Peng C Y, Nanayakkara A, Challacombe M, Gill P M W, Johnson B, Chen W, Wong M W, Gonzalez C, Pople J A, Gaussian 03W, revision C.02 Gaussian, Inc., Wallingford, CT, 2004.16

48. Becke A D 1993 J. Chem. Phys. 985648

49. Lee C, Yang W and Parr R G 1998 Phys. Rev. B 37785

50. Schaefer A, Hube C and Ahlrichs R 1994 J. Chem. Phys. 1005829

51. Schaefer A, Horn H and Ahlrichs R 1992 J. Chem. Phys. 972571

52. Sheldrick G M 1990 SHELXS-97, Göttingen, Germany: University of Göttingen

53. Sheldrick G M 1997 SHELXL-97, Program for the refinement of crystals structures from diffraction data, Göttingen, Germany: University of Göttingen

54. Patra D, Pattanayak P, Pratihar J L and Chattopadhyay S 2007 Polyhedron 26484

55. Ray U, Chand B, Mostafa G, Cheng J, Lu T-H and Sinha C 2003 Polyhedron 222587
56. Pattanayak P, Pratihar J L, Patra D, Puranik V G and Chattopadhyay S 2008 Polyhedron 272209

57. Saluzzo C and Lemaire M 2002 Adv. Synt. Catal. 344 915

58. Harmon R E, Gupta S K and Brown D J 1973 Chem. Rev. 7321

59. Pintar A and Batista J 1999 Catal. Today 5335

60. Mallat T, Bodmer M and Baiker A 1997 Catal. Lett. 44 95

61. Venkatachalam $\mathrm{G}$ and Ramesh R 2005 Tetr. Lett. 46 5215

62. Kannan S, Ramesh R and Liu Y 2007 J. Organomet. Chem. 6923380

63. Pratihar J L, Bhaduri S, Pattanayak P, Patra D and Chattopadhyay S 2009 J. Organomet Chem. 6943401

64. Bianchini C, Peruzzini M, Farnetti E, Kagpar J and Graziani M 1995 J. Organomet Chem. 48891

65. Clapham S E and Morris R H 2005 Organometallics 24 479

66. Bianchini C, Farnetti E, Graziani M, Peruzzini M and Polo A 1993 Organometallics 123753 